\title{
Spatio-Temporal analysis and Water Quality Indices
} (WQI): case of the Ébrié Lagoon, Abidjan, Côte d'Ivoire

\author{
Naga Coulibaly 1,", Talnan Jean Honoré Coulibaly ${ }^{1}$, Henoc Sosthène Aclohou ${ }^{1}$, \\ Ziyanda Mpakama ${ }^{2}$, Issiaka Savané ${ }^{1}$ \\ Laboratoire de Géosciences et Environnement, UFR des Sciences et gestion de l'Environnement, Université \\ NANGUI ABROGOUA, Abidjan; coulibalynaga_sge@una.edu.ci, ctalnan@yahoo.fr, \\ sothenehenoc@gmail.com, savanei@hotmail.com \\ 2 Programme Manager Africa Regional Centre I Stockholm International Water Institute (SIWI), Pretoria, \\ South Africa; ziyanda.mpakama@siwi.org \\ * Correspondence: coulibalynaga_sge@una.edu.ci, Tel: +225-05-83-75-99
}

\begin{abstract}
For decades, the Ébrié Lagoon in Côte d'Ivoire has been the receptacle of wastewater effluent and household waste transported by runoff water. This work assesses the spatio-temporal variability of the Ébrié lagoon water quality at the city of Abidjan. The methodological approach used in this study is summarized in three stages: the choice and standardization of the parameters for assessing water quality for uses such as aquaculture, irrigation, watering, and sports and recreation; the weighting of these parameters using the Hierarchical Analysis Process (AHP) of Saaty; and finally, the aggregation of the weighted parameters or factors. Physicochemical and microbiological analysis data on the waters of the Ébrié lagoon for June and December of 2014 and 2015 were provided by the Ivorian Center for Anti-Pollution (Centre Ivoirien Anti-Pollution, CIAPOL) and the concentrations of trace elements in sediments ( $\mathrm{As}, \mathrm{Cd}, \mathrm{Cr}, \mathrm{Pb}, \mathrm{Zn}$ ) were used. The aggregation of standardized and weighted parameters allowed the determination of the Water Quality Indices (WQI) by usage for each bays of the lagoon. The results show that in both 2014 and 2015, the waters of the Ébrié lagoon were generally of poor quality for the different uses examined in this study (aquaculture, irrigation, watering and sport and recreation) with an accentuation in 2015. However, some bays of the lagoon have waters of dubious to satisfactory quality. This study contributes an improved evaluation of the Ébrié lagoon waters.
\end{abstract}

Keywords: water quality indices; spatio-temporal analysis; ébrié lagoon; surface water; Abidjan

\section{Introduction}

The coast of Côte d'Ivoire has a remarkable lagoon system. Although originally exceptional, the natural environments associated with this lagoon complex are now severely degraded, due to the intense human pressure exercised on this fragile space over decades. Since the 1970s and because of the development of the city of Abidjan, there has been increasing concern about this damage. Indeed, Côte d'Ivoire's industrial development has been heavily concentrated in the metropolitan area of Abidjan. In 2010, the National Institute of Statistics (Institut national de la statistique, INS) determined that $92.8 \%$ of the 2822 industrial establishments in the country are located in the only economic capital of the country (Abidjan) and $60 \%$ of these establishments are installed around the Ébrié lagoon. The Ébrié lagoon has several bays in which untreated or insufficiently treated wastewater effluents (domestic, industrial wastewater and so forth) or solid waste have been discharged for decades [1]. The biodegradable waste causes an intense eutrophication phenomena, especially in the low renewal areas such as bays [2]. To determine the quality of Ébrié lagoon water many studies have been conducted since the 1980s [2-16]. These studies were focused on the assessment of biological and microbiological quality, pollution by oil, metal sediment contamination, 
and solid waste. Additionally, the Ivorian Center of Anti-Pollution (Centre Ivoirien d'Anti-Pollution, CIAPOL) as part of its mission, systematically and periodically analyzes the natural waters from its National Observation Network (Réseau National d'Observation, RNO). Thus, the water quality of the Ébrié lagoon is periodically analyzed in situ and in a laboratory, as part of the monitoring of this water body. Based on this important existing knowledge base on the Ébrié Lagoon, it is now necessary to introduce a Water Quality Indices (WQI) approach, which summarizes large quantities of data on water quality in to simple terms of water quality (Excellent, Good, Bad, and so forth), in order to supply synthetic and comprehensive information to the decision makers and the general public. WQIs minimize the volume of data and simplify the expression of water quality status based on a number of physicochemical and bacteriological parameters [17]. The first attempts to classify water by degree of purity date back to the mid-twentieth century [18]. Horton's pioneering efforts have been followed by number of researchers; various WQIs have been formulated and used by water supply and water pollution control agencies around the world [19-32].

Because the Ébrié lagoon plays an important role in Côte d'Ivoire's economic development, it is necessary to develop indicators on the quality of these waters that are simplified and easily understood to support valuation of the lagoon waterbody. Thus, the main objective of this study is to perform a spatio-temporal assessment of the Ébrié lagoon water quality for uses such as aquaculture, irrigation, watering and sport and recreation using a multicriteria analysis method.

\section{Materials and Methods}

\subsection{Study Area}

The Ébrié lagoon is part of the Ivorian lagoon complex that was formed by tectonic depressions, causing a lagoon fault [33]. The Ébrié lagoon area is $523 \mathrm{~km}^{2}$ [34]. The volume of this lagoon is about 2.5 billion of $\mathrm{m}^{3}$, the average depth is $4.8 \mathrm{~m}$ and some pits near Abidjan exceed $20 \mathrm{~m}$ in depth. The lagoon waters are separated from the Gulf of Guinea (Atlantic Ocean) by a set of recent dune cordons formed in the Holocene period less than 10,000 years ago.

The climate of the region is of an equatorial type of transition characterized by four seasons with a heavy rainfall in the month of June $(367 \mathrm{~mm})$. The average annual rainfall in the district of Abidjan is between 1600 and $2400 \mathrm{~mm}$. The Ébrié lagoon is fed mainly by continental fresh waters from the Comoé, Agnéby and Mé Rivers and has been open to marine waters since 1950 via the Vridi channel, while its natural outlet, the Comoé pass at Grand-Bassam, is now closed. The Comoé River alone is responsible for $70 \%$ of the freshwater inflow to the lagoon. The inputs of this river are charged with fertilizer and pesticide residues and, periodically, with aquatic plants (freshwater hyacinth). The central part of the Ébrié lagoon is chief concern of this study where the metropolitan area of Abidjan is located (Figure 1). The city of Abidjan, the economical capital of Côte d'Ivoire, has a population of 4.707 million inhabitants as of 2014, living in ten communes (Abobo, Adjamé, Attécoubé, Cocody, Koumassi, Marcory, Plateau, Port-Bouët, Treich-ville and Yopougon). Most of the country's industries are concentrated in Abidjan. The pollution of the lagoon is caused by excessive inputs of untreated domestic and industrial effluents (soap factories, oil mills, breweries, dairies, refineries, and so forth) and all kind of solid waste. The Ébrié lagoon is currently considered a reservoir of pathogenic bacteria. 


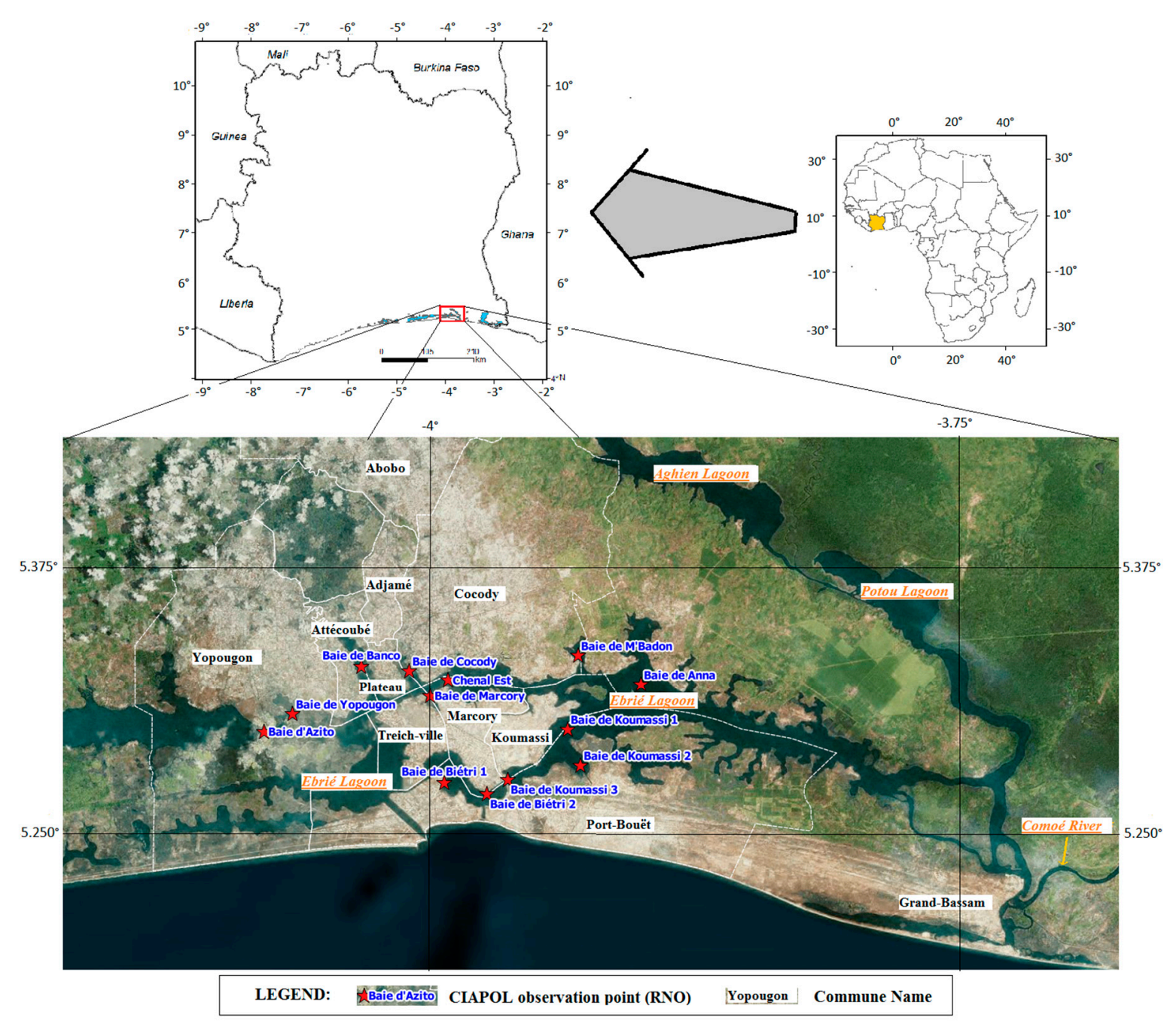

Figure 1. Presentation of Ébrié lagoon and the study area.

\subsection{Data}

The data used in this study are the water and sediment quality of the Ébrié Lagoon and the map of the district of Abidjan. Data on the physico-chemical and biological quality of Ébrié lagoon water have been provided by the CIAPOL. These data are the results of in situ and laboratory analyses of samples taken on the surface of the lagoon waterbody during the months of June and December in 2014 and 2015. In this study, thirteen stations of the RNO of CIAPOL located at the Ébrié lagoon were considered. Also, this study includes an analysis of the trace metal elements (Arsenic, Cadmium, Total Chromium, Lead, Zinc) present in the sediments of the Ébrié lagoon bays extracted from Kouamé et al. [15]. The map of Abidjan at 1/25000 from the "Centre d'Information Géographique et du Numérique" (CIGN) of the "Bureau National d'Etude Technique et de Développement" (BNETD) was used to extract the limits of the lagoon and the communes of Abidjan. All of the data were analyzed using the free open source software, Quantum GIS (QGIS) as well as the maps composition. QGIS is a GIS software which supports a number of data formats: vector (Shapefile, ArcInfo, Mapinfo, GRASS GIS, etc.), raster (GRASS GIS, GeoTIFF, TIFF, JPG, etc.) and spatial databases.

\subsection{Methods}

\subsubsection{Parameters of Different WQIs by Use and Their Classification}

Various parameters were selected for each type of use (see Table 1): Irrigation, watering, aquaculture, and sports and recreation. This parameters are those use in the SEQ-eau (Système 
d'Evaluation de la Qualité de l'eau). SEQ-eau is a tool used to evaluate and characterize the physicalchemical and microbiology of surface water or groundwater.

Table 1: Parameters used for different uses.

\begin{tabular}{|c|c|}
\hline Usages & Parameters \\
\hline Sports and recreation & $\begin{array}{l}\text { Total suspended solids (TSS), Total Coliform (C.Total), Enterococci, Thermotolerant } \\
\text { Coliforms (C.Thermo), SECCHI Transparency (Secchi) }\end{array}$ \\
\hline Irrigation & $\begin{array}{l}\text { Total Coliform (C.Total), Thermotolerant Coliforms (C.Thermo), Lead (Pb), Copper } \\
(\mathrm{Cu}) \text {, Nickel, Total Chrome (Cr), Arsenic (As), Cadmium (Cd), Zinc (Zn), Chlorides, } \\
\text { Selenium }\end{array}$ \\
\hline Watering & $\begin{array}{l}\mathrm{NO}_{2}{ }^{-} \text {, Nitrates (N), Sodium, Calcium, Sulfate, Free cyanide, Zinc }(\mathrm{Zn}) \text {, Copper }(\mathrm{Cu}) \text {, } \\
\text { Selenium, Arsenic (As), Mercury, Lead (Pb), Nickel, Cadmium(Cd), Total Chrome } \\
(\mathrm{Cr})\end{array}$ \\
\hline Aquaculture & $\begin{array}{l}\text { Chlorophyll a + pheopigments, } \mathrm{NO}_{2}{ }^{-} \text {, Free Cyanides, Mercury, NH4+, Phosphor (P), } \\
\text { Oxygen }(\mathrm{O}) \text {, Calcium, Copper }(\mathrm{Cu}) \text {, Zinc }(\mathrm{Zn}) \text {, Nitrates }(\mathrm{N}) \text {, TSS, pH, DBO5, } \\
\text { Mercury, Lead }(\mathrm{Pb}) \text {, Nickel, Cadmium }(\mathrm{Cd}) \text {, Total Chrome }(\mathrm{Cr})\end{array}$ \\
\hline
\end{tabular}

According to the uses and the observed values, each parameter was qualitatively classified in terms of: Good quality, satisfactory quality, dubious quality, poor quality, and very bad quality. This classification was carried out according to the SEQ-eau model. Then, for each class we assigned a code (codification) ranging from 0 to 100, which was used in the analysis as the quality that estimates the parameter; 80 corresponds to good quality and 0 corresponds to a very poor quality of water (Table 2).

Table 2. Water quality index classes and codes.

\begin{tabular}{|c|c|c|}
\hline Aptitude class & Color & Description \\
\hline $80(80-100)$ & Blue & Good quality \\
\hline $60(60-80)$ & Green & $\begin{array}{l}\text { Satisfactory } \\
\text { quality }\end{array}$ \\
\hline $40(40-60)$ & Yellow & Dubious quality \\
\hline $20(20-40)$ & Orange & Bad quality \\
\hline $0(0-20)$ & Red & Very bad quality \\
\hline
\end{tabular}

\subsubsection{Evaluation Method: Weighted Factor Aggregation}

The assessment of the different Water Quality Indices (WQI) of the Ébrié Lagoon consisted of the aggregation or combination of weighted factors (parameters). Thus, these indices were calculated using the following formula:

$$
\mathrm{WQI}=\frac{\sum q_{i} w_{i}}{\sum w_{i}}
$$

where,

$q_{i}$ is the quality that estimates the $\mathrm{n}^{\text {th }}$ parameter;

$W_{i}$ is the weight of the $\mathrm{n}^{\text {th }}$ parameter.

In this study, the method used to determine the weights of the parameters is the Analytic Hierarchy Process (AHP) created by Saaty [35]. The weighting of the decision criteria was performed using pair-wise comparisons through the Analytic Hierarchy Process (AHP). 
129

130

131

132

133

134

135

\section{Results}

\subsection{Weighting of Parameters Per Usage}

Through the AHP method, the parameters weights of the different uses were determined to allow the evaluation of the Water Quality Indices. Table 3 summarizes the different weights obtained for the WQIs of aquaculture, sports and recreation, irrigation and watering. For each use the sum of the weights for each index is equal to 1.

Table 3. Parameter weights for different uses.

\begin{tabular}{|c|c|c|c|c|c|c|c|}
\hline \multicolumn{2}{|c|}{ Aquaculture } & \multicolumn{2}{|c|}{ Sport and recreation } & \multicolumn{2}{|c|}{ Irrigation } & \multicolumn{2}{|c|}{ Watering } \\
\hline Parameter & weight & Parameter & weight & Parameter & weight & Parameter & weight \\
\hline $\mathrm{Cd}$ & 0,16 & TSS & 0.33 & As & 0.135 & As & 0.16 \\
\hline $\mathbf{P b}$ & 0,13 & Secchi & 0.23 & $\mathbf{P b}$ & 0.2 & $\mathrm{~Pb}$ & 0.2 \\
\hline $\mathrm{Zn}$ & 0,15 & C.Total & 0.19 & $\mathrm{Cd}$ & 0.2 & $\mathrm{Cd}$ & 0.17 \\
\hline $\mathrm{O}$ & 0,08 & C.Thermo & 0.11 & $\mathrm{Zn}$ & 0.21 & $\mathrm{Zn}$ & 0.2 \\
\hline $\mathbf{P}$ & 0,05 & Enterococci & 0.14 & $\mathrm{Cr}$ & 0.18 & $\mathbf{N}$ & 0.04 \\
\hline $\mathrm{pH}$ & 0,035 & Sum & 1 & C.Total & 0.041 & $\mathrm{NO}_{2}^{-}$ & 0.08 \\
\hline $\mathrm{Cr}$ & 0,13 & & & C.Thermo & 0.034 & $\mathrm{Cr}$ & 0.15 \\
\hline MES & 0,03 & & & Sum & 1 & Sum & 1 \\
\hline $\mathbf{N}$ & 0,07 & & & & & & \\
\hline $\mathrm{NO}_{2}^{-}$ & 0,08 & & & & & & \\
\hline $\mathrm{NH}_{4}{ }^{+}$ & 0,085 & & & & & & \\
\hline Sum & $\overline{1}$ & & & & & & \\
\hline
\end{tabular}

3.2. Spatio-Temporal Analysis of WQIs

\subsubsection{Water Quality Index for Aquaculture}

Figure 2a shows the water quality of the lagoon for the month of June 2014. There is bad to very bad water quality in the bays located in the north of the Ébrié Lagoon except at the Bay of Yopougon where the quality is dubious. The southern bays have bad quality water for aquaculture except Koumassi 1 where the quality is dubious. During the same month (June) in 2015, the waters of the bays of Ébrié lagoon are generally of bad to very bad quality (Figure 2b). In December 2014, the quality of the waters of the bays located in the north of the lagoon is generally worse than those of the south (Figure 2c). This trend is statistically conserved in the same month of 2015 (Figure 2d). 

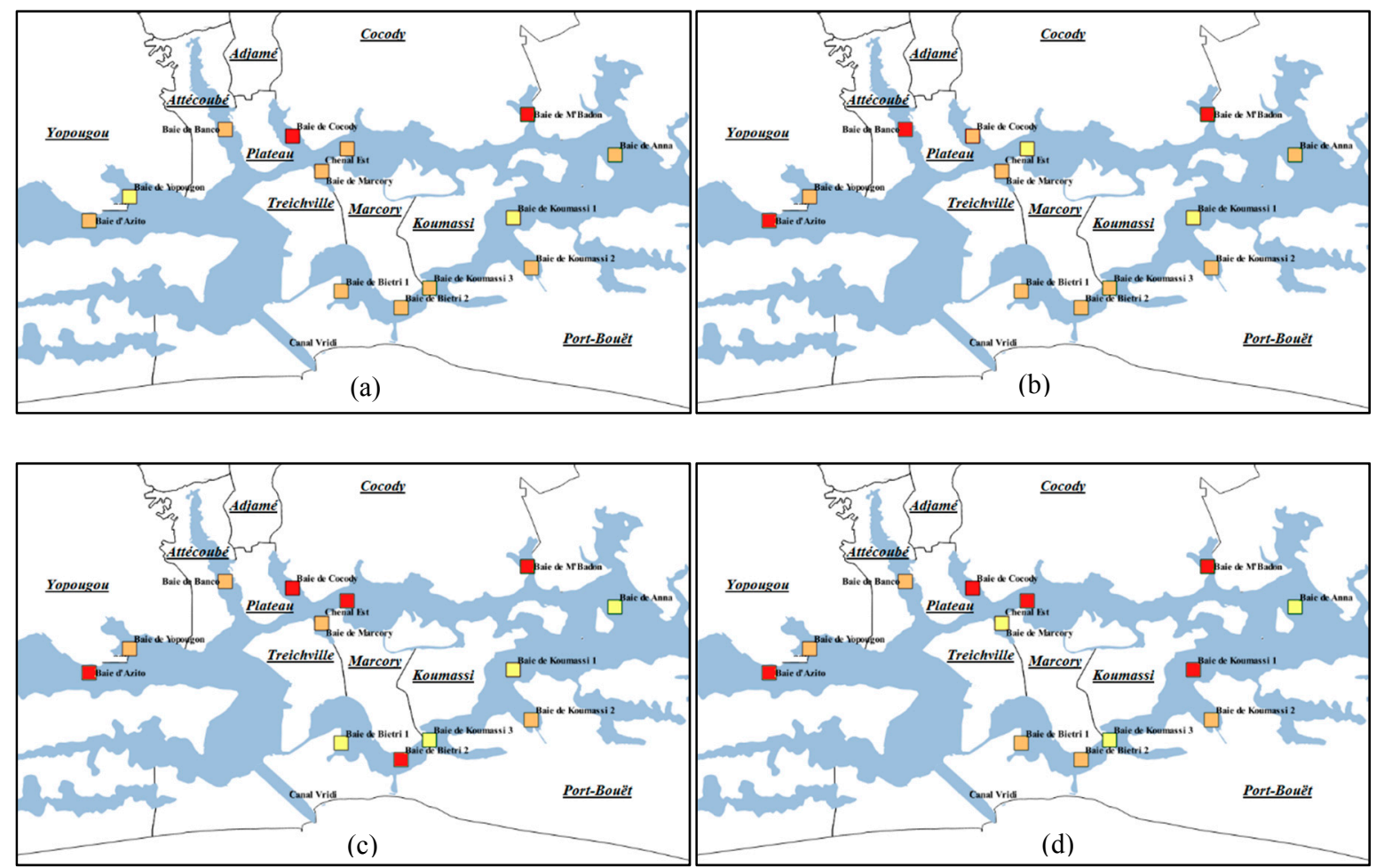

\begin{tabular}{|llll|}
$\square$ Good quality & $\square$ Dubious quality & Very bad quality & Plateau Commune name \\
$\square$ Satisfactory quality & $\square$ Bad quality & Ebrié Lagoon & \\
\hline
\end{tabular}

Figure 2. Spatio-temporal variation of the Water Quality Index for aquaculture: (a) June 2014 (b) June 2015, (c) December 2014 and (d) December 2015.

\subsubsection{Water Quality Index for Sport and Recreation}

During the month of June 2014 we observe that the quality of the Ébrié lagoon waters is dubious to bad for sport and recreation (Figure 3a). Only the Bay of Anna has satisfactory water quality. In 2015, during the month of June the quality of the waters of the lagoon deteriorated further (Figure 3b). In particular, water in the bay of Cocody went from bad to very bad. The December 2014 results (Figure 3c) show that the water quality varies from dubious to very bad (bays of Biétri 1 and 2 and Koumassi 3). The spatial variation in water quality in December 2015 (Figure 2d) is identical to the variation in December 2014: the changes are at the bays of Koumassi 1 and Canal Est, where the quality went from dubious in 2014 to bad quality in 2015. 

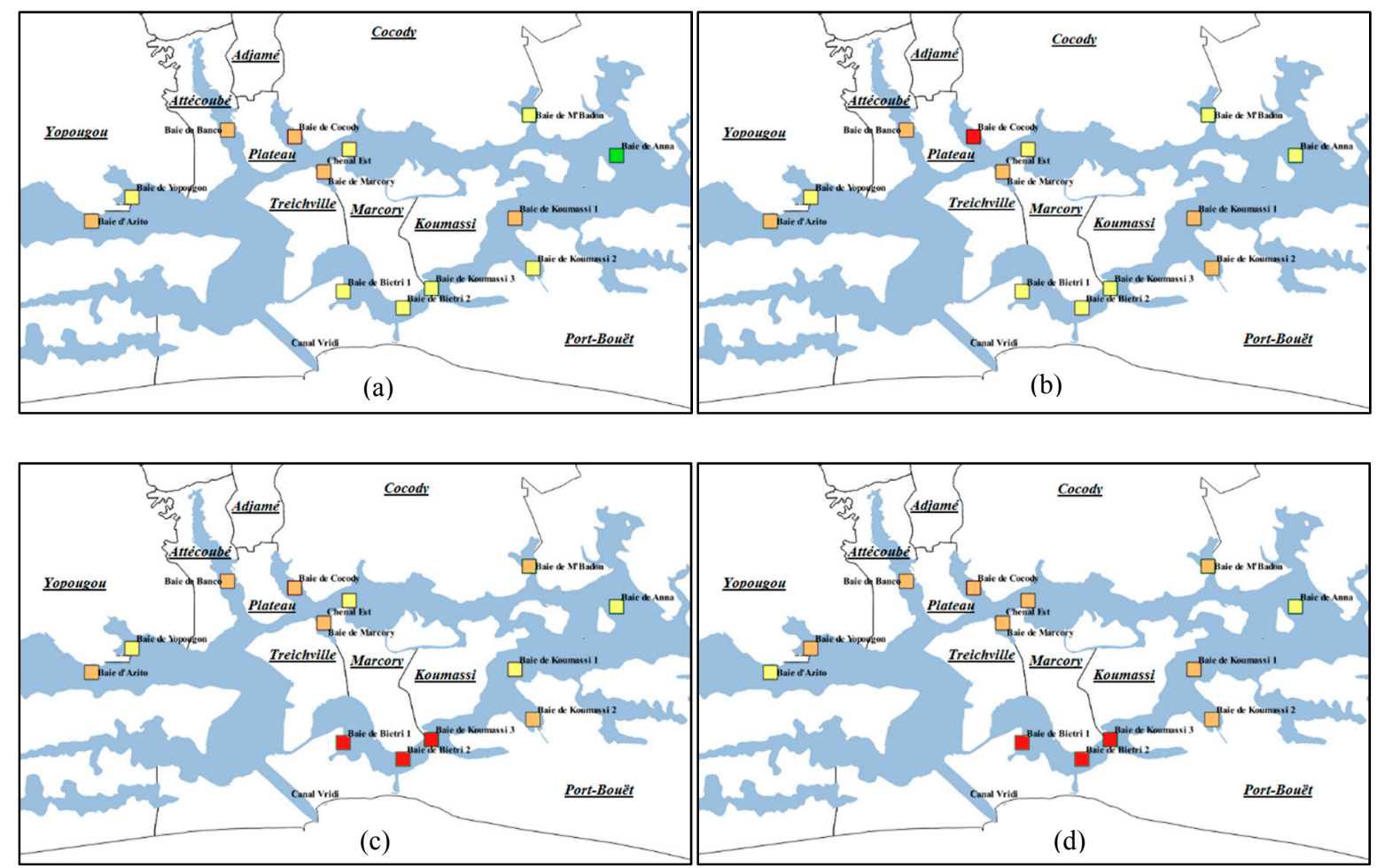

\begin{tabular}{|llll|}
$\square$ Good quality & $\square$ Dubious quality & Very bad quality & Plateau Commune name \\
$\square$ Satisfactory quality & $\square$ Bad quality & Ebrié Lagoon & \\
\hline
\end{tabular}

Figure 3: Spatio-temporal variation of the Water Quality Index for sports and recreation: (a) June 2014

(b) June 2015, (c) December 2014 and (d) December 2015.

\subsubsection{Water Quality Index for Irrigation}

The records for the month of June 2014 show that the lagoon water quality was of bad quality for the purpose of irrigation (Figure 4a) except for the bays of Yopougon and Koumassi 1 where the waters were of dubious quality and at Azito where the quality is very bad. In June 2015, the lagoon water quality varied between bad to very bad quality (the latter being observed at Azito). During the months of December, the lagoon water quality is overall bad or very bad in both 2014 (Figure 4c) and 2015 (Figure 4d). However, we notice that the degree of pollution is greater in 2015 than it was in 2014. In fact, the bays of Cocody and Koumassi 2 which were of bad quality in 2014, deteriorated to very bad quality in 2015 . 

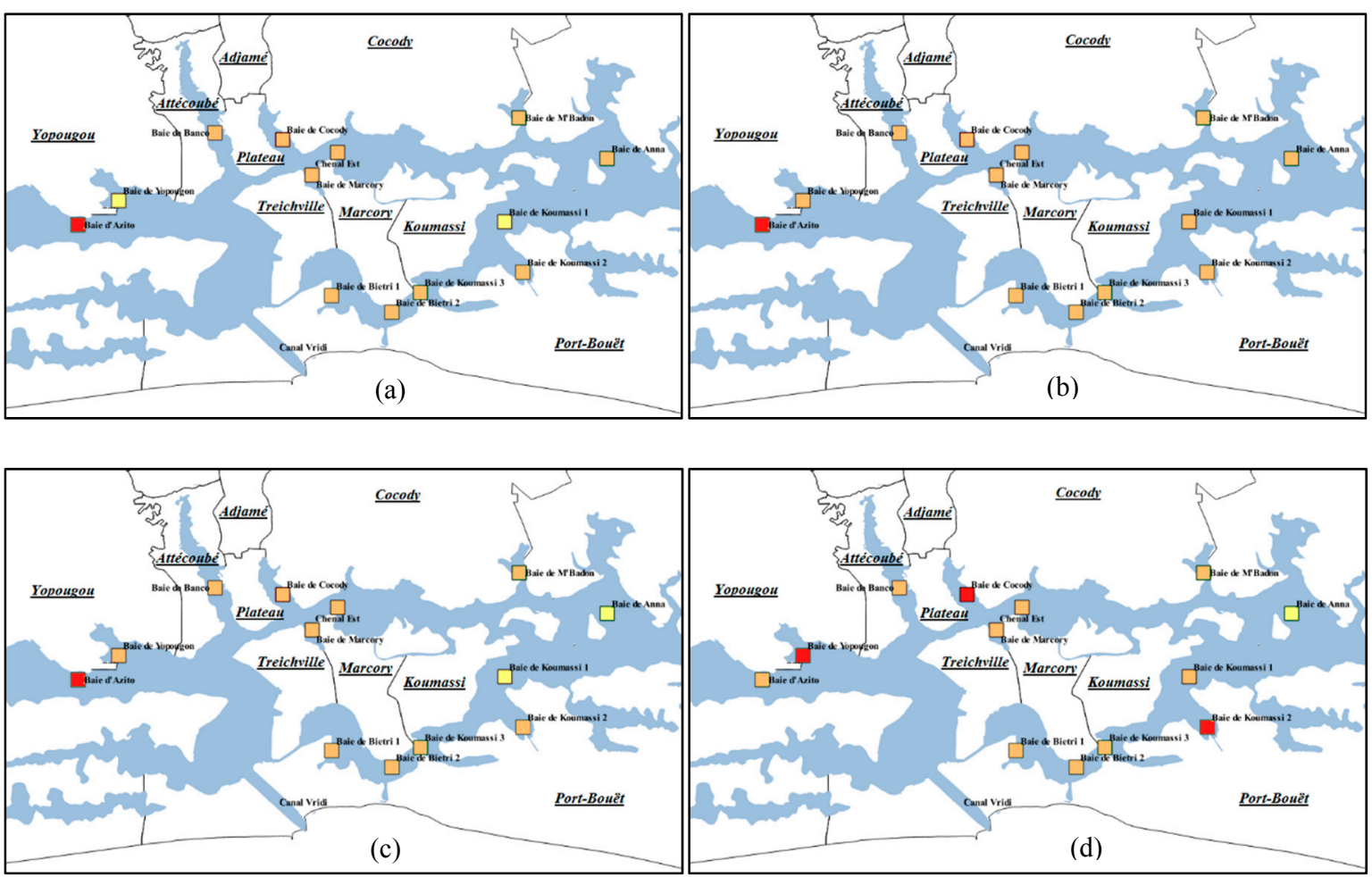

\begin{tabular}{|llll|}
\hline$\square$ Good quality & $\square$ Dubious quality & $\square$ Very bad quality & Plateau Commune name \\
$\square$ Satisfactory quality & $\square$ Bad quality & Ebrié Lagoon & \\
\hline
\end{tabular}

Figure 4: Spatio-temporal variation of the Water Quality Index for irrigation: (a) June 2014 (b) June 2015, (c) December 2014 and (d) December 2015.

\subsubsection{Water Quality Index for Watering}

Figure 5a shows that the lagoon's water quality varies from dubious to very bad quality for watering in June 2014. The quality is generally bad to very bad in June 2015 (Figure 5b). The water quality in the bay of Anna remained dubious for watering from June 2014 to June 2015. In December 2014, the water quality for watering at all observation points varied from satisfactory quality (at Anna) to very bad quality at Cocody and Azito. In December 2015, the waters of the lagoon bays varied from dubious quality (bays of Banco, Koumassi 1 and Canal East) to very bad quality (bays of 

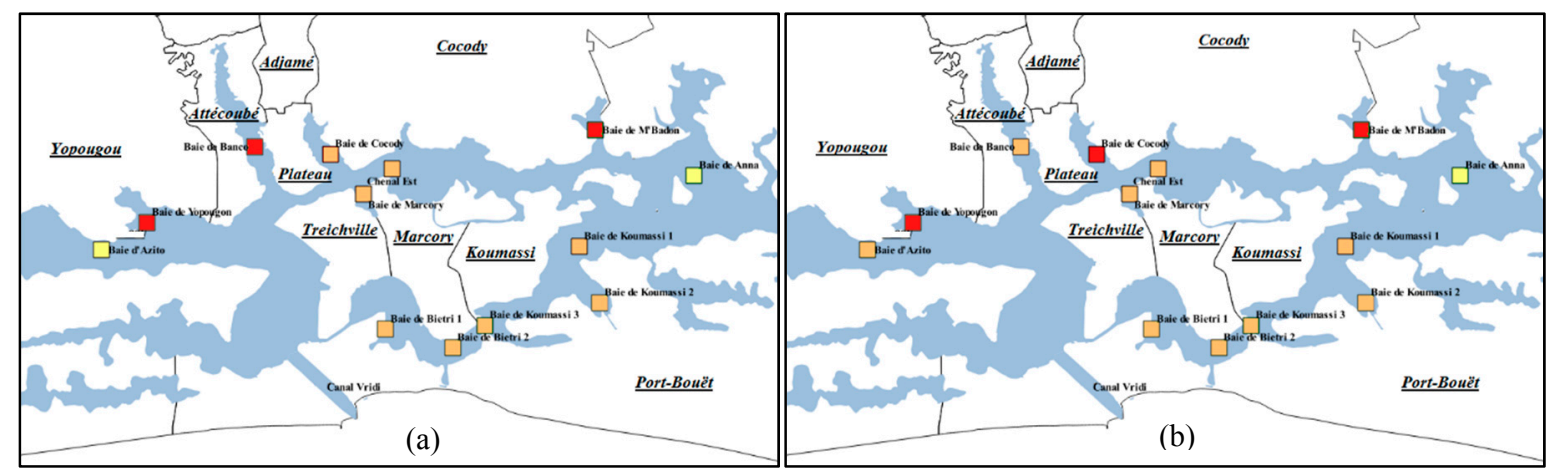

187
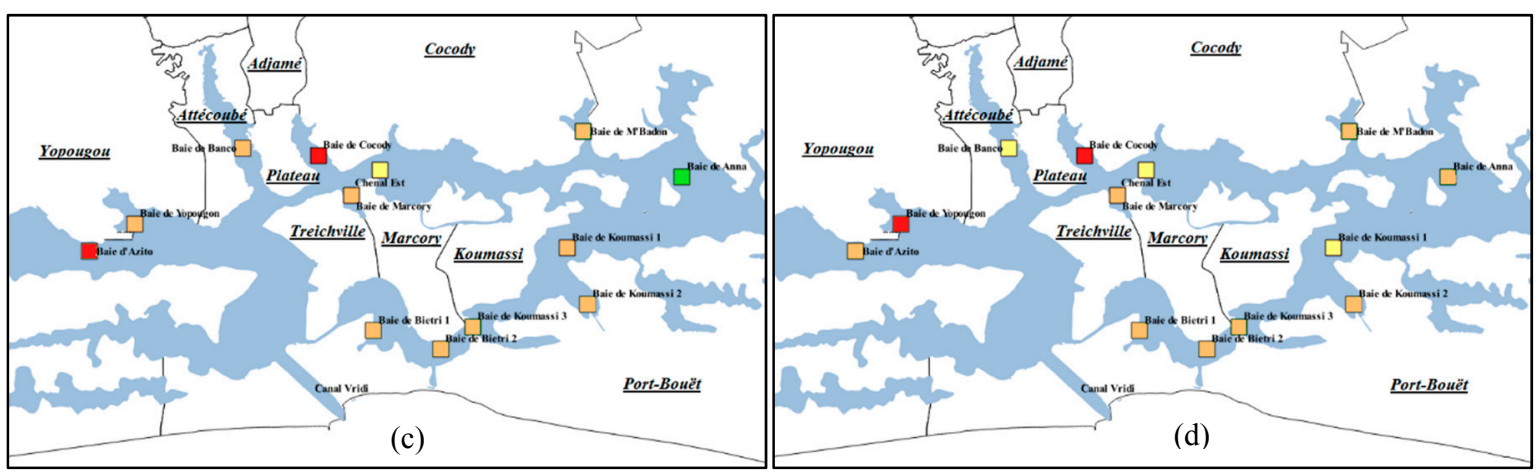

Figure 5: Spatio-temporal variation of the Water Quality Index for watering: (a) June 2014 (b) June 2015, (c) December 2014 and (d) December 2015.

\section{Discussion}

The water quality of the Ébrié lagoon bays was analyzed in time and space for four uses (aquaculture, irrigation, Recreation and Sports and watering) during the months of June and December of 2014 and 2015 using a Water Quality Index (WQI) method. The obtained results depend on the chosen parameters and their classification of these parameters according to their different concentrations. For example, the interpretation of these concentrations as "good" or "bad". They also depend on the weighting of the parameters or their perceived importance to the overall quality of water [36-39]. In this study, for the choice and standardization of parameters we relied on the SEQeau version 2 method [40-42]. Then, for the determination of the weights or relative importance of the parameters, we used the AHP method developed by Saaty [43]. This method reduces the subjectivity of the weighting process. The results we obtained generally confirm the observations on the ground which testifies to the robustness of our approach.

The Water Quality Indices (EQI) of the Ébrié lagoon calculated in this study indicate that the water's quality varies from dubious to very bad quality generally for the four uses: aquaculture, irrigation, watering and sports and recreation. These results are explained by the discharge into the lagoon of household waste, faeces, residues of food industries and waste materials for several decades. Indeed, the different bays of the Ébrié lagoon are receptacles for urban, industrial and runoff effluents from the ten communes of Abidjan [1,10,14,44]. Additionally, Koné and Aka [45] showed that all the industries of the Abidjan agglomeration dumped their wastewater in the lagoon, with a total volume estimated at $12,000 \mathrm{~m}^{3}$ per day. These inputs are likely to contain metallic trace elements (ETM) such as lead ( $\mathrm{Pb})$, chromium (Cr), zinc ( $\mathrm{Zn})$, arsenic (As) and cadmium (Cd) [15]. Kouamé et al. [46] observed a very large bioaccumulation of $\mathrm{Cr}$ and $\mathrm{Pb}$ in crab organisms (used as indicators of metal pollution) collected in the Ébrié lagoon. 
The bays of the Ébrié lagoon located in the urban area of Abidjan that are directly subjected to the domestic pollutants have water of bad quality for the uses considered in this study. The bays of Cocody, Biétri, Marcory, Azito, M'Badon and Koumassi have overall bad quality for the different uses. The bays of Yopougon, Cocody, Marcory and Koumassi are particularly exposed to pollution. In the communes of Yopougon, the various bays of the lagoon receive all effluents from households and the wastewater from the industrial zone of this commune. At the Cocody Bay, there is an outfall that receives the contaminated water and solid waste from the storm water network. This bay also receives sewage from several areas of the communes of Adjamé, Abobo and Yopougon [12]. The bay of Marcory, enclaved, receives the sewage of the commune due to frequent breakdowns in the wastewater network. M'Badon Bay is polluted by leachate from the uncontrolled landfill of the city of Abidjan upstream [14,47-48]. We note that the bay of Anna is the least polluted. This is because the drainage basin that drains this bay is the least urbanized. In some places, the obtained quality class may seem to contradict field observations. For example, at M'Badon Bay, the method used in this study resulted in a dubious quality assessment for recreation and sport, whereas it should have been bad quality, due to the outlet of leachate effluent from the uncontrolled landfill of the city of Abidjan. These exceptions can be explained by the noncompleteness of the parameters used for the evaluation of the water quality (see Table 1). As an example, we can define a "solid waste" parameter for the amount of solid waste that reaches the different banks of the lagoon. The spatio-temporal analysis pointed out that from 2014 to 2015 some bays show improving water quality-for example, from very bad to bad, or from bad to dubious, despite the fact that polluting flows are permanent and increase with time. This may be due to the hydrological regime of the Ébrié Lagoon. In fact, river flows from Comoé, Mé and Agnéby contribute towards diluting the waters of the lagoon, thus reducing pollution according to Durand and Guiral [49].

\section{Conclusions}

This study involved a spatio-temporal analysis of the water quality of the Ébrié lagoon at the city of Abidjan, the economic capital of Côte d'Ivoire. The selected parameters used in this analysis were those defined by SEQ-eau for the uses of: irrigation, sport and recreation, aquaculture and watering. The method consisted of calculating Water Quality Indices (WQIs) for the different selected uses using a weighted factor aggregation approach. The results of the assessment of the water quality of the Ébrié lagoon for June and December of 2014 and 2015 have shown that the quality of the water of the studied bays varies from dubious to very bad quality for all uses: Aaquaculture, irrigation, recreation and sports and watering. According to the results of this study, the projected opening of the mouth of the Comoé River could deprive the lagoon of $70 \%$ of its input water flow, which is crucial for the renewal of lagoon's waters. On this basis, it would not be judicious to open the mouth of Comoé River at Grand Bassam.

The values of the WQIs obtained in this study depend on the day of the sampling as well as the parameters considered for evaluation. Thus, to take into account the specificity of the city of Abidjan, it would be relevant to further consider how best to determine the specific Water Quality Indices for the Ébrié lagoon. A statistical approach could be used to identify relevant parameters. Also, this study can be extended to different rivers and lakes in Côte d'Ivoire, as classifying them would allow better management of the water resources of the country.

Acknowledgments: The authors thank the Centre Ivoirien d'Anti-Pollution (CIAPOL) of the Ministre de la Salubrité, de l'Environnement et du Développement Durable (MINSEDD) who produced data for this work and the SGIE for the framework of collaboration around environmental information of Côte d'Ivoire the coastal zone.

Author Contributions: Coulibaly Naga developed the idea, Aclohou Henoc Sosthène prepared data and evaluated the WQIs. Coulibaly Naga, Coulibaly Talnan J. H. contributed to the analyses, interpretation of results and wrote the paper. Ziyanda Mpakama and Savané Issiaka revised the paper.

Conflicts of Interest: The authors declare no conflicts of interest. 


\section{References}

1. Dufour, P.; Aka, K.; Lanusse, A.; Les pollutions en Environnement et ressources aquatiques de Côte d'Ivoire. Les milieux lagunaires. T. 2 Edit. Orstom, 1994, Vol.5, pp. 309-333.

2. Zabi, S.G.; Les peuplements benthiques liés à la pollution en zone urbaine d'Abidjan (Côte d'Ivoire) Oceanologica Acta, suppl, 1982,4, 441-455.

3. Marchand, M ; Martin, JL ; Détermination de la pollution chimique (hydrocarbures, organochlorés, métaux) dans la lagune d'Abidjan (Côte d'Ivoire) par l'étude des sédiments. Océanogr. Trop., 1985,., 20(1), 26-39.

4. Métongo, B.; Kaba, N.; Kouassi, A.; Evaluation quantitative et qualitative des effluents et des polluants. Cas de la Côte d'Ivoire et de la ville d'Abidjan. Doc. Centre de Recherche Océanologiques, Abidjan, Rapport du contrat de recherche, 1993, 100p.

5. Kouassi, A.M.; Kaba, N.; Métongo, B.S.; Land-based sources of pollution and environnemental quality of the Ébrié lagoon waters. Mar. Pollut. Bull., 1995, 30(5), 295-300.

6. Adingra AA, Arfi R.. Organic and bacterial pollution in the Ébrié lagoon, Côte d'Ivoire. Mar. Pollut. Bull., 1998, 36(9), 689-695.

7. Scheren P.A.G.M.; Kroeze, C.; Janssen, F.J.J.G.; Hordijk, L; Ptasinski, K.J.; Integrated water pollution assessment of the Ébrié Lagoon, Ivory Coast, West Africa. Journal of Marine Systems, 2004, 44: 1- 17, http://dx.doi.org/10.1016/j.jmarsys.2003.08.002

8. Yao, K.M.; Métongo, B.S.; Trokourey, A.; Bokra, Y.; Détermination de certains paramètres de pollution dans les baies d'une lagune tropicale: la lagune Ébrié (Côte d'Ivoire). J. Ivoir. Océanol. Limnol. 2007, 4(1), $1-10$.

9. Coulibaly, A.S.; Monde, S.; Wognin, V.A.; Aka, K.; State of antropic pollution in the estuary of Ébrié lagoon (Côte d'Ivoire) by analysis of the metal traces. Eur. J. of Sci. Res., 2008, 19(2), 371-390.

10. Soro, G.; Metongo, S.B. ; Soro, N. ; Ahoussi, K.E. ; Kouamé, K.F. ; Zadé, S.G.P. ; Soro, T.; Métaux lourds $(\mathrm{Cu}, \mathrm{Cr}, \mathrm{Mn}$, et $\mathrm{Zn})$ dans les sédiments de surface d'une lagune tropicale africaine. Cas de la lagune Ébrié (Côte d'Ivoire), Int. J. Biol.Chem. Sci., 2009, 3, 1408-1427.

11. Adingra, A.A.; Kouassi, A.M.F.; Pollution en lagune Ébrié et ses impacts sur l'environnement et les populations riveraines. Tech. \& Doc. Vulg. 2011， 48-53.

12. Coulibaly, T.J.H.; Coulibaly, N.; Koffi, D.; Camara, M.; Savane, I.; Cartographie des zones à l'origine de l'ensablement des canaux du bassin versant du Gourou (Abidjan - Côte d'Ivoire). IJIAS, 2014, 6, 642653.

13. Inza, B.; Yao, K.M.; Paramètres physiques et chimiques et métaux lourds des eaux de la Lagune Ébrié (Côte d'Ivoire) : influence de la marée et des effluents liquides urbaines. J. Mater. Environ. Sci. 2015, 6 (5) 1321-1329.

14. Akpo, S.K. ; État de la pollution fécale dans les baies de la lagune Ébrié (Banco, Cocody et M’Badon) à Abidjan, Côte d'Ivoire. J. Mater. Environ. Sci., 2016, 7, 621-630.

15. Kouamé, K.D.; Yapo, O.B.; Miété, L.; Contamination des sédiments d'une lagune tropicale urbaine par les éléments traces métalliques ( $\mathrm{As}, \mathrm{Cd}, \mathrm{Cr}, \mathrm{Pb}, \mathrm{Zn}$ ) : cas des baies lagunaires de la ville d'Abidjan (Côte d'Ivoire), Int. J. Pure App. Biosci., 2016, 4(6), 204-217, doi: http://dx.doi.org/10.18782/2320-7051.2428

16. Tia, L.; Gestion Des Matières Résiduelles Et Pollution Lagunaire A Abidjan : Responsabilités, Stratégies et Perspectives. European Scientific Journal, 2017, 13(2), 1857-7881. http://dx.doi.org/10.19044/esj.2016.v13n2p378

17. Bordalo, A.A.; Teixeira, R.; Wiebe, W.J.; A water quality index applied to an international sharedriver basin: The case of the Douro River, Environmental Management, 2006, 38, 910-920.

18. Horton, R.K.; An index number system for rating water quality. J. Water Pollut. Control Fed., 1965, 37, 300-306.

19. Richardson, A.M.; Development of an Estuarine Water Quality Index (WQI) for New South Wales. Dissertation B.Sc. (Honours), University of Sydney, 1997, 148p.

20. Cash, K. J., Saffran, K. A. et Wright, C. R., (2001) Application of Canadian Water Quality Index to PPWB Monitoring Program, Technical Report, Vol.1, pp. 205-230

21. Lumb, A.; Halliwell, D.; Sharma, T.; Canadian Water Quality Index to Monitor the Changes in Water Quality in the Mackenzie River-Great Bear. In: Proceedings of the29thAnnual Aquatic Toxicity Workshop, (2002, Oct.21-23), Whistler, B.C., Canada. 
22. Debels, P.; Figueroa, R.; Urrutia, R.; Barra, R.; Niell, X.; Evaluation of water quality in the Chillan River (Central Chile) using physicochemical parameters and a modified water quality index. Environ. Monit. Assess., 2005, 110, 301-322.

23. Akoteyon, I.S.; Omotayo, A.O.; Soladoye, O.; Olaoye, H.O.; Determination of water quality index and suitability of urban river for municipal water supply in Lagos, Nigeria. Eur J Sci Res, 2011, 54(2), 263271

24. Semiromi, F.B.; Hassani, A.H.; Torabian, A.; Karbassi, A.R.; Lotfi, F.H.; Water quality index development using fuzzy logic: A case study of the Karoon River of Iran. African Journal of Biotechnology, 2011, 10, 10125-10133.

25. Abbasi, T.; Abbasi, S; Water Quality Indices, 1st Edition. Elsevier, ISBN 9780444638366, 2012 P 384

26. Wanda, E.M.; Gulula, L.C.; Phiri, G.; Determination of characteristics and drinking water quality index in Mzuzu City, Northern Malawi. Physics and Chemistry of the Earth, Parts A/B/C 2012, 50: 92-97.

27. Tyagi, S.; Sharma, B.; Singh, P.; Dobhal, R.; Water quality assessment in terms of water quality index. American Journal of Water Resources, 2013, 1, 34-38.

28. Bhutiani, R.; Khanna, D.R.; Kulkarni, D.B.; Ruhela M.; Assessment of Ganga river ecosystem at Haridwar, Uttarakhand, India with reference to water quality indices. Appl Water Sci., 2014, doi: 10.1007/s13201-014-0206-6

29. Akter, T.; Jhohura, F.T.; Akter, F.; Chowdhury, T.R.; Mistry, S.K.; Dey, D.; Barua, M.K.; Islam, M.A.; Rahman, M.; Water Quality Index for measuring drinking water quality in rural Bangladesh: a crosssectional study. J Health Popul Nutr, 2016, 35(4), doi:10.1186/s41043-016-0041-5

30. Imneisi, I.B.; Aydin, M.; Water Quality Index (WQI) for Main Source of Drinking Water (Karaçomak Dam) in Kastamonu City, Turkey. J Environ Anal Toxicol, 2016, 6, 407, doi:10.4172/2161-0525.1000407

31. Bora, M.; Goswami, D.C.; Water quality assessment in terms of water quality index (WQI): case study of the Kolong River, Assam, India. Appl Water Sci, 2017, 7, 3125. Doi:https://doi.org/10.1007/s13201-0160451-y

32. Şener, Ş.; Şener, E.; Davraz, A.; Evaluation of water quality using water quality index (WQI) method and GIS in Aksu River (SW-Turkey). ELSEVIER, Science of The Total Environment, 2017, 15, 131-144, doi:https://doi.org/10.1016/j.scitotenv.2017.01.102

33. Tastet, J-P; Guiral, D.; Géologie et sédimentologie. In Environnement et Ressources Aquatiques de Côte d'Ivoire. Tome II. Les Milieux Lagunaires. 1994, Editions ORSTOM; 59-90.

34. Pottier, P.; Affian, K.; Djagoua, M’M.V., Anoh, K.P.; Kra, Y.; Kangah, A.; Robin, M.; La lagune Ébrié à l'épreuve de la pression anthropique (in P.POTTIER et K. P. ANOH Géographie du littoral de la Côte d'Ivoire : éléments de réflexion pour une politique de gestion intégrée. Coopération Universitaire Cocody Abidjan (Côte d'Ivoire)/Nantes (France) 2008,325p.

35. Saaty, T. L. (1980) The Analytic Hierarchy Process: Planning, Priority setting, Resource allocation, McGraw-Hill, New York, 19 p.

36. Bharti, N; Katyal, D.; Water quality indices used for surface water vulnerability assessment. Inter. J. Of Envir. Sc., 2011, 2(1) 154-173.

37. Sharma, S.; Reddy, A. S.; Development of Water Quality Indices for Designated Best Uses of Surface Water Body. IJESIT, 2013, 2(5)

38. Tirkey, P.; Bhattacharya, T.; Chakraborty, S.; Water quality indices- important tools for water quality assessment: a review. IJAC, 2013, 1(1), 15-28.

39. Lachhab, A; Beren, M; Zuidervliet, B.; Middle Creek Water Assessment Using Water Quality Index (WQI). Journal of the Pennsylvania Academy of Science, 2014, 88, 4-12.

40. SEQ-EAU., Système d'évaluation de la Qualité de l'Eau des cours d'eau. Rapport d'étude des Agences de l'Eau. 2003, Rapport de présentation SEQ-EAU Version2,.

41. Hanadi, I.; Zaher; Z., Samer F.; Hussein, A.-H.; Comparative Analysis Of Results Obtained From 3 Indexes (SEQ-Eau, IBD, IPS)Used To Assess Water Quality Of The Berdawni, A Mediterranean Stream At The Beqaa Region - Lebanon. IJSTR, 2015, 4(3), 34-40.

42. Hanadi, I.; Hussein A.-H.; Yolla B.; Ahmad C.; Comparative Analysis of Two Indices (SEQ-Eau and IBMR) to Assess Water Quality of The Ghouzaiel, AMediterranean Streamat Beqaa Region - Lebanon. IJASTR, 2016, 6(1), 357-366.

43. Saaty, T.L.; Fundamentals of Decision Making and Priority Theory with the Analytic Hierarchy Process, kindle Edition Pittsburgh, PA 15260 USA. 2000Vol. 6, 478p. 
44. Halle, B., Buzon, V., Profil Environnemental de Côte d'Ivoire. Offre de service dans le secteur de la coopérative relatif au contrat cadre Europe Aid, 2006, Vol.10, pp. 133.

45. Koné, M.; Aka, K.; () Les lagunes d'Abidjan asphyxiées par la pollution. Africa Geosciences Review, 3, 1995, 461-470.

46. Kouamé, K.D.; Yapo, O.B.; Méité L.; Heavy metal concentrations in some benthic organisms (callinectes amnicola) from Ébrié lagoon, Abidjan Côte d'Ivoire. Asian Journal of Science and Technology, 2017, 8(11), 6681-6685.

47. Adjiri, O.A.; Goné, D.L.; Kouamé, I.K.; Kamagaté B.; Biémi J.; Caractérisation de la pollution chimique et microbiologique de l'environnement de la décharge d'Akouédo, Abidjan-Côte d'Ivoire. Int. J. Biol. Chem. Sci., 2008, 2(4), 401-410.

48. Adjiri, O.A.; Mafou, C.K.; Konan P.K.; Impact de la décharge d'Akouédo (Abidjan - Côte d'Ivoire) sur les populations: étude socio-économique et environnementale. IJIAS, 2015, 13(4), 979-989.

49. Durand, J. R.; Guiral, D.; Hydroclimat et hydrochimie. en Environnement et ressources aquatiques de Côte d'Ivoire. Les milieux lagunaires. T. 2 Edition Orstom, 1994, Vol.5, pp. 59-90. 